Goldschmidt 2021 Abstract

https://doi.org/10.7185/gold2021.5861

\section{Thermodynamic model for the refertilization of the non-cratonic continental mantle lithosphere.}

\author{
JULIETTE PIN ${ }^{1}$, LYDÉRIC FRANCE ${ }^{1}$, LAURIE \\ REISBERG $^{1}$ AND SARAH LAMBART ${ }^{2}$ \\ ${ }^{1}$ Université de Lorraine, CNRS, CRPG \\ Presenting Author: juliette.pin1@etu.univ-lorraine.fr
}

${ }^{2}$ University of Utah

In a classic model of evolution of the non-cratonic continental mantle lithosphere, harzburgites are refractory $(<5 \%$ clinopyroxene) and represent the residue of partial melting of a fertile mantle composed of lherzolites ( $>5 \%$ clinopyroxene). However, partial melting is not the only process that could explain the peridotite compositional variability that ranges from fertile ( $>2$ wt. $\% \mathrm{Al}_{2} \mathrm{O}_{3},<45 \mathrm{wt}$. \% $\mathrm{MgO}$ ) to refractory ( $<2 \mathrm{wt}$. $\%$ $\mathrm{Al}_{2} \mathrm{O}_{3},>45$ wt. $\% \mathrm{MgO}$ ). In the refertilization process, harzburgite is a refractory protolith that undergoes reactive percolation of silicate melts, derived from the underlying asthenosphere and causing the crystallization of a new generation of minerals (mostly clinopyroxene). Here we use phMELTS [1,2] and a simple impregnation model to independently constrain the role of five different parameters, pressure, temperature, redox conditions, and compositions of the percolated rock and of the percolating melt (hereafter referred as $\mathrm{P}-\mathrm{T}-\mathrm{fO}_{2}-\mathrm{X}_{\pi}-\mathrm{X}_{\text {melt }}$ ), during the refertilization process, and compare these results with observed suites of peridotites. The evolution of the modal composition, together with the major element variations, are evaluated. The main results are that first, the produced model is consistent with the global peridotite database, and second, $\mathrm{T}, \mathrm{fO}_{2}$ and small variations of pressure have almost no impact on the evolution of the system. The percolated harzburgite modal composition has an effect on the variation of the modal proportions. The parameter with the most significant impact is $\mathrm{X}_{\text {melt }}$, which is directly linked to the geodynamic context and to melting conditions. This parameter directly controls the refertilization reaction and so, the phase composition. Incompatible element (e.g., $\mathrm{Na}$ ) depletions in natural residual assemblages are lower than those predicted from the simple impregnation model, indicating instead that the process occurs in open systems, and that reactive percolation likely results in incompatible element enrichment in the associated melt. Our results corroborate that most of the spectrum of compositional variability observed in lithospheric mantle peridotites can be explained by the impregnation of primitive silicate melt in refractory harzburgites.

[1] Smith \& Asimow (2005), Geochemistry, Geophysics, Geosystems, vol. 6, $\mathrm{n}^{\circ} 2$.

[2] Asimow et al. (2004), Geochemistry, Geophysics, Geosystems, vol. $5, \mathrm{n}^{\mathrm{o}} 1$.

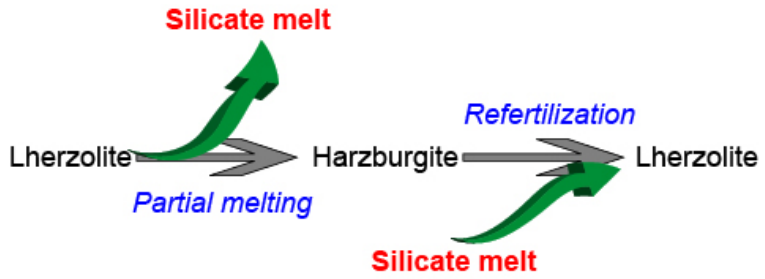

Silicate melt 